\title{
PROGNOZY PODAŻY I POPYTU NA PRACĘ W PRZEMYŚLE WLÓKIENNICZYM I ODZIEŻOWYM W WOJEWÓDZTWIE ŁÓDZKIM
}

\begin{abstract}
Streszczenie
Celem artykułu jest analiza zmieniającego się rynku pracy w przemyśle włókienniczo-odzieżowym oraz określenie przyszłej sytuacji specjalistów z sektora włókienniczo-odzieżowego na wojewódzkim rynku pracy. Autorka dokonuje oceny bieżacego i prognozowanego (w perspektywie 2025 roku) popytu i podaży na kwalifikacje i umiejętności absolwentów szkół zawodowych o profilu włókienniczoodzieżowym z województwa łódzkiego.
\end{abstract}

Słowa kluczowe: rynek pracy, przemysł włókienniczo-odzieżowy, popyt na pracę, podaż pracy

\section{FORECASTED SUPPLY AND DEMAND FOR LABOUR IN TEXTILE AND CLOTHING INDUSTRY IN LÓDZKIE VOIVODESHIP}

\begin{abstract}
Summary
This paper aims to analyse the changing labour market in the textile and clothing sector and to predict the future prospects of the industry's professionals on the regional labour market. The author reviews the current and forecasted (for 2025) supply and demand for the qualifications and skills of the graduates from the region's vocational schools specialising in textiles and clothing.
\end{abstract}

Key words: labour market, textile and clothing industry, labour demand, labour supply

\section{Wstęp}

Główną gałąź działalności przemysłowej Lodzi przez wiele lat stanowił przemysł włókienniczy i odzieżowy. Wraz z początkiem lat dziewięćdziesiątych minionego wieku nastały w łódzkim sektorze włókienniczo-odzieżowym gwałtowne zmiany, w wyniku których upadło wiele, często bardzo dużych, przedsiębiorstw. W następstwie między innymi tych procesów na rynku pracy pojawiła się ponad 20-procentowa rzesza bezrobotnej ludności czynnej zawodowo. Upadek wielu wielkich zakładów włókienniczych zmienił strukturę wytwarzania w tym sektorze.

\footnotetext{
${ }^{1}$ dr Anna Rogozińska-Pawełczyk - adiunkt w Katedrze Pracy i Polityki Społecznej, Uniwersytet Lódzki; e-mail: arogozinska-pawelczyk@wp.pl.
} 
Obecnie nie ma już przedsiębiorstw zatrudniających powyżej tysiąca pracowników. Ich miejsce zajęły firmy zatrudniające co najwyżej kilkaset osób, bardziej elastyczne i innowacyjne, często stosujące bardzo nowoczesne technologie i materiały oraz surowce nowej generacji [Rogut, 2007, s.13]. Z rynku pracy odchodzą na emeryturę starsi pracownicy, zaś w miejsce dawnych, tradycyjnych stanowisk pracy powstaje zapotrzebowanie na pracowników reprezentujących zaawansowane technologie. Wydaje się, że w tej sytuacji dostateczna i odpowiednia liczba dobrze wykształconych pracowników na rynku może ukazać istotne perspektywy dalszego rozwoju tego sektora.

Perspektywy rozwojowe sektora włókienniczego określa, z jednej strony, istniejący potencjał przedsiębiorstw działających w tym obszarze, a z drugiej, opinia przedsiębiorców dotycząca możliwości dalszej ekspansji na rynku, a w związku z tym planowanie przez nich dalszych działań personalnych. Zatem jest wymagana zmiana profilu produkcji włókienniczo-odzieżowej na rzecz koncentracji na promowaniu tych rodzajów działalności, które cechują się relatywnie wyższą wartością dodaną i mniejszą wrażliwością na konkurencję z innych państw (np.: szycie ubrań zorientowanych na górny segment rynku, wdrażanie nowych materiałów czy kreacja mody). To, z kolei, pociąga za soba znaczne zmiany na rynku pracy, gdyż najmniej płatne, najprostsze zawody stają się mniej potrzebne, a jednocześnie rośnie znaczenie zawodów zaawansowanych technologicznie, np.: specjalistów do spraw obsługi maszyn włókienniczych, technologów materiałów i innych. Nowe rozwiazzania organizacyjne w przemyśle i nowe techniki w sferze zarządzania również wymagają zastosowania nowej wiedzy i narzędzi informatycznych [Por. Program Ramony rozwoju szkolnictwa zawodowego..., 2012, s. 5].

Zmiany strukturalne, jakie miały miejsce $\mathrm{w}$ minionych dekadach $\mathrm{w}$ przemyśle włókienniczym i odzieżowym, wywołuja potrzebę podejmowania systematycznych badań w celu identyfikacji nowych potrzeb innowacyjnej gospodarki. Wobec powyższego, niniejszy artykuł ma na celu przedstawienie obecnej i przyszłej sytuacji specjalistów z sektora włókienniczo-odzieżowego na wojewódzkim rynku pracy. Zostało to dokonane przez wskazanie bieżącego i prognozowanego popytu i podaży na kwalifikacje i umiejętności absolwentów szkół zawodowych o profilu włókienniczo-odzieżowym z województwa łódzkiego.

Analiza była prowadzona w skali całego województwa łódzkiego. Jej podstawę stanowiły w znacznej części dane empiryczne uzyskane w wyniku badań ankietowych, zrealizowanych w latach 2011-2012 w ramach projektu „Szyte na miarę kwalifikacje przyszłością sektora włókienniczo-odzieżowego w województwie łódzkim"2. Badania ankietowe przeprowadzono w szkołach zawodowych z województwa łódzkiego, kształcących w zawodach o profilach włókienniczo-odzieżowych, wśród dyrektorów/nauczycieli $(\mathrm{N}=40)$ i wśród uczniów $(\mathrm{N}=400)$. Ponadto, badaniami objęto również przedsiębiorców z terenu województwa łódzkiego, zatrudniających absolwentów szkół zawodowych z wykształceniem o profilu włókienniczo-odzieżowym $(\mathrm{N}=400)$. Badania miały charakter ilościowy. Zastosowano warstwowo-losowy dobór próby, co pozwoliło

\footnotetext{
2 Projekt badawczy pt. „Szyte na miarę kwalifikacje przyszłością sektora włókienniczo - odzieżowego w województwie łódzkim", współfinansowany przez Unię Europejską z Europejskiego Funduszu Społecznego, był realizowany przez firmę BROST Centrum Edukacji i Technologii Komputerowej w partnerstwie z Agencją Analiz Statystyczno-Ekonomicznych „An-Stat” oraz Stowarzyszeniem Włókienników Polskich.
} 
na zapewnienie odpowiedniej reprezentacji badanej populacji oraz dokonanie szczegółowej analizy i odniesienie sformułowanych wniosków do całej populacji. Wyniki badań empirycznych dodatkowo zostały uzupełnione o źródła danych pochodzących z GUS, m.in. Banku Danych Lokalnych i MEN - Systemu Informacji Oświatowej³.

\section{Zmiany na rynku pracy w przemyśle włókienniczo-odzieżowym w perspektywie roku 2025}

Prognoza przyszłych zmian na rynku pracy w sektorze włókienniczo-odzieżowym wiąże się z koniecznością zbadania relacji między liczbą uczniów w szkołach zawodowych, zajmujących się kształceniem przyszłych pracowników firm włókienniczo-odzieżowych (czyli liczbą absolwentów tych szkół) a liczbą ludności w wieku 15-19 lat (czyli populacja, która potencjalnie trafia do szkół zawodowych).

Szacunki dla lat: 2015, 2020 i 2025 zostały przeprowadzone odrębnie dla absolwentów techników (średnich szkół zawodowych) i zasadniczych szkół zawodowych.

\subsection{Szacunek podaży pracowników $\mathrm{z}$ wykształceniem technicznym zawodowym w przemyśle włókienniczo-odzieżowym}

W celu oszacowania tendencji zmian podaży pracowników pracujących w zawodach technik odzieży i włókiennik dla lat: 2015, 2020 i 2025, potrzebne będą dane o: zmianach stanu ludności w wieku produkcyjnym w kolejnych okresach pięcioletnich, liczbie ludności w wieku 15 - 19 lat w kolejnych okresach pięcioletnich, liczbie techników wchodzacych w danym okresie w wiek emerytalny, a także informacje na temat liczby absolwentów ponadgimnazjalnych szkół zawodowych, kształcących w zawodach technika odzieży i włókiennika. W formie prognoz demograficznych GUS są publikowane jedynie dane dotyczące ludności, więc brakujące dane należy oszacować, przyjmując określone założenia o relacjach liczebności techników w poszczególnych grupach wiekowych.

Zakładając, że struktura wiekowa techników odzieży i techników włókienników jest względnie wyrównana w poszczególnych rocznikach, można stwierdzić, że zmniejszenie się liczby ludności w wieku produkcyjnym w kolejnych okresach pięcioletnich oznacza redukcję liczby techników, zgodnie z proporcją obserwowaną w roku wyjściowym 2010. Założenie stałości udziału liczby techników w ogólnej liczbie ludności w wieku produkcyjnym dla poszczególnych grup wiekowych jest arbitralne i może być polemiczne. W najbliższych latach w wiek emerytalny wejda bowiem absolwenci

\footnotetext{
${ }^{3}$ Do opracowania niniejszego artykułu wykorzystano także informacje zawarte w następujących raportach cząstkowych, opracowanych w ramach projektów: „Analiza sytuacji społeczno-demograficznej województwa łódzkiego w kontekście potrzeb sektora włókienniczo-odzieżowego”, „Analiza porównawcza rynku pracy sektora włókienniczo-odzieżowego na obszarach wiejskich i miejskich”, „Analiza porównawcza potencjału szkolnictwa zawodowego o profilu włókienniczo-odzieżowym na obszarach miejskich i wiejskich”, „Analiza oferty edukacyjnej szkół zawodowych w kontekście potrzeb sektora włókienniczo-odzieżowego”, „Dobre praktyki w sektorze włókienniczo-odzieżowym - raport benchmarkingowy”, „Przyszłość zawodów w sektorze włókienniczo-odzieżowym".
} 
szkół zawodowych z lat, kiedy sektor włókienniczo-odzieżowy zatrudniał znacznie więcej pracowników (w tym techników), a szkolnictwo zawodowe kształciło dużo większą liczbę młodzieży w tych specjalnościach. Taki stan rzeczy może oznaczać niedostateczne doszacowanie liczby techników wychodzących z rynku pracy, szczególnie w latach 2015 i 2020, a w konsekwencji przeszacowanie podaży techników odzieży i włókienników. Jednak zakładany szacunek może okazać się bliski rzeczywistości ze względu na fakt, iż spośród tych pracowników z sektora włókienniczo-odzieżowego, którzy stracili pracę w latach dziewięćdziesiątych, większość z pewnością zorganizowała sobie życie zawodowe, na przykład przekwalifikowując się, zatrudniając się w usługach lub w innych sektorach gospodarki. Nawet, jeżeli osoby te formalnie posiadaja wykształcenie w specjalnościach włókienniczo-odzieżowych, to realnie nie można już ich uważać za potencjalnych pracowników. Stąd przedstawione założenie zostaje podtrzymane.

Oszacowanie liczby absolwentów z wykształceniem zasadniczym zawodowym jest nieco trudniejsze. Według danych Systemu Informacji Oświatowej ${ }^{4}$, w ostatnich latach liczba uczniów w szkołach zasadniczych zawodowych spadała. W latach 2009-2011 wynosiła odpowiednio: 327, 268 i 216 osób. Liczba absolwentów szkół zawodowych w tych samych latach wynosiła odpowiednio: 128, 74 i 88 osób. Na podstawie zaprezentowanych danych można przypuszczać, że stale zmniejszająca się liczba uczniów pociaga za sobą zmniejszająca się liczbę absolwentów tych szkół. Do celów symulacji przyjęto, że w latach 2011-2015 średniorocznie naukę będzie kończyło 62 uczniów, czyli łącznie w okresie pięciu lat takich osób będzie 310. Taka liczba absolwentów powinna podlegać korekcie ze względu na, zapewne niewielką, grupę osób podejmujących studia po ukończeniu szkoły średniej. Z uwagi na brak jakichkolwiek wiarygodnych informacji na ten temat, przyjęto umownie, że liczbę tę należy skorygować o $10 \%$. Szacowana liczba pracowników pracujących w zawodach technik odzieży i włókiennik, zasilających rynek pracy w latach 2011-2015, wyniesie zatem 279 osób. Odnosząc tę liczbę do liczby ludności w wieku 15-19 lat, obliczono wskaźnik, który służy wycenie liczby techników odzieży i włókienników wkraczających na rynek pracy:

$$
\delta=279 / 150332=0,0019 \text {. }
$$

Wskaźnik ten oszacuje liczbę techników na podstawie informacji o przyroście liczby ludności w wieku produkcyjnym w pięcioleciu 2011 - 2015. Liczba ta pokrywałaby się z liczba ludności w wieku 15-19 lat w roku 2010, gdyby nie istniało zjawiska migracji i ubytków naturalnych, czyli zgonów.

Dodatkowo, należy się zastanowić nad sposobem oceny przewidywanych kierunków zmian w systemie kształcenia techników odzieży i włókienników. Przyjmując w wariancie podstawowym zachowanie obecnej skuteczności naboru do szkół średnich, zakłada się, że kształcenie młodzieży w tych zawodach pozostanie nadal atrakcyjna ofertą dla zbliżonej liczby osób z wykształceniem gimnazjalnym. Zmiany będą mogły nastapić jedynie w przypadku podjęcia przez szkoły zawodowe, a także przez pracodawców zintensyfikowanych działań marketingowych. Powinny one polegać na aktywizacji pracodawców, którzy we własnym interesie szeroko rozwijaliby współpra-

4 Por. Baza Danych Systemu Informacji Oświatowej (SIO) Ministerstwa Edukacji. 
cę ze szkołami, zarówno w formie wsparcia finansowo-organizacyjnego, jak i pod względem programowym. Brak zmian w tym kierunku może oznaczać dalszą zapaść w kształceniu w specjalnościach włókienniczo-odzieżowych. Skutkować to może tym, iż za kilkanaście lat może okazać się, że brak wykwalifikowanej kadry technicznej zmusi pracodawców do samodzielnego kształcenia techników w szkołach przyzakładowych, co jest rozwiązaniem z pewnością znacznie droższym od rozwijania różnych form wsparcia dla istniejących publicznych szkół zawodowych.

W celu zarysowania ewolucji rynku pracy techników odzieży i techników włókienników, przyjęto trzy scenariusze zmian:

1. Wariant podstawowy, który będzie oznaczał, że w przyszłości zostaną utrzymane relacje liczby absolwentów do liczby młodzieży w wieku 15-19 lat (przyjęte do obliczenia współczynnika $\delta$ );

2. Wariant pesymistyczny, czyli zapaść kształcenia w zawodach włókienniczoodzieżowych, postępująca w tempie 5\% rocznie (o tyle średniorocznie zmniejszają się współczynniki naboru uczniów, a w konsekwencji liczba absolwentów, w kolejnych latach od 2012 do 2025);

3. Wariant optymistyczny, który będzie oznaczał, iż współczynniki zwiększają się w tym samym tempie, w wyniku wspólnych działań szkół i przedsiębiorców.

Poniżej dokonano oszacowań podaży pracowników z wykształceniem średnim technicznym w specjalnościach włókienniczych na podstawie przedstawionego wyżej wskaźnika, w trzech wariantach prognostycznych: pesymistycznym, podstawowym i optymistycznym. Wyniki wyliczeń przedstawia tabela 1.

TABELA. 1.

Szacunek podaży pracowników ze średnim wykształceniem w specjalnościach włókienniczo-odzieżowych w latach 2010-2025

\begin{tabular}{|c|c|c|c|c|c|c|}
\hline \multirow{2}{*}{ Lata } & \multicolumn{2}{|c|}{ Wariant pesymistyczny } & \multicolumn{2}{c|}{ Wariant podstawowy } & \multicolumn{2}{c|}{ Wariant optymistyczny } \\
\cline { 2 - 7 } & osoby & $\mathbf{2 0 1 0 = 1 0 0}$ & osoby & $\mathbf{2 0 1 0 = 1 0 0}$ & osoby & $\mathbf{2 0 1 0 = 1 0 0}$ \\
\hline 2010 & 2031 & 100,0 & 2031 & 100,0 & 2031 & 100,0 \\
2015 & 1851 & 91,1 & 1909 & 94,0 & 1967 & 96,8 \\
2020 & 1751 & 86,2 & 1855 & 91,3 & 2031 & 100,0 \\
2025 & 1686 & 83,0 & 1831 & 90,2 & 2195 & 108,1 \\
\hline
\end{tabular}

Źródło: obliczenia własne na podstawie danych GUS (BDL) i Ministerstwa Edukacji (SIO).

W wariancie pesymistycznym podaż będzie w całym okresie spadać do $83 \%$ poziomu z roku $2010 \mathrm{w} 2025$. W wariancie podstawowym spadek podaży techników odzieży i włókienników wyniesie 6\% w roku 2015, niemal 9\% w 2020 roku i prawie $10 \%$ w 2025 roku. W scenariuszu optymistycznym, po początkowym spadku w latach 2012-2015, nastapi wzrost w roku 2025 do ponad 108\% liczby techników z 2010 roku. 


\subsection{Szacunek podaży absolwentów zasadniczych szkół zawodowych kształcących w zawodach włókienniczo-odzieżowych}

Wyniki badania ankietowego, przeprowadzonego wśród przedsiębiorstw sektora włókienniczo-odzieżowego, pozwalają na sformułowanie konkluzji, iż przeważająca grupa zatrudnionych w firmach włókienniczo-odzieżowych w województwie są osoby z wykształceniem zasadniczym. Ich udział to aż 57,4\% ogólnej liczby pracowników.

Procedura postępowania podczas oszacowania podaży pracowników z wykształceniem zasadniczym zawodowym jest analogiczna do tego, jaka była dokonana w przypadku techników. Jedyna różnica występuje w braku wprowadzenia korekty ze względu na kontynuację nauki na poziomie wyższym.

W latach 2007 i 2008 uczyło się w zasadniczych szkołach zawodowych w województwie łódzkim odpowiednio 160 i 168 uczniów, a w latach 2010 i 2011 - 207 i 150 uczniów5. W latach 2010 i 2011 liczba absolwentów wynosiła 85 i 86 osób. Zatem do szacunków przyjęto utrzymanie poziomu z roku 2011, co oznacza, że oczekiwana liczba absolwentów wyniesie średniorocznie 86 osób. Analiza liczby uczniów i absolwentów w zasadniczych szkołach zawodowych o profilu włókienniczo-odzieżowym nie daje podstaw do określenia wyraźniejszej tendencji zmian. Uzupełniając liczbę uczniów oceną liczby osób odchodzących z grupy pracowników w wieku produkcyjnym, otrzymuje się oszacowane na tej podstawie wartości podaży pracowników z wykształceniem zasadniczym zawodowym.

Poniżej dokonano oszacowań podaży pracowników z wykształceniem zasadniczym zawodowym w specjalnościach włókienniczych na podstawie przedstawionych wskaźników, w trzech wariantach prognostycznych: pesymistycznym, podstawowym i optymistycznym. Wyniki wyliczeń przedstawia tabela 2.

We wszystkich wariantach - pesymistycznym, podstawowym i optymistycznym jest szacowany głęboki spadek liczby osób (absolwentów szkół zawodowych) - potencjalnych pracowników sektora włókienniczo-odzieżowego. Skala spadku jest podobna w każdym wariancie - o około 40\% w stosunku do roku bazowego 2010.

Niezależnie od przyjętych założeń, kierunek zmian na rynku pracy będzie miał przebieg zbliżony do przedstawionego. Cokolwiek bowiem zostanie założone o sytuacji w szkołach zawodowych, ich zdolność do rekrutacji uczniów zainteresowanych praca w sektorze włókienniczo-odzieżowym pozostanie na poziomie wynikającym z aktualnych możliwości. Stąd trzeba uwzględnić fakt konkurencji innych kierunków nauczania, w tym także takich, które mają renomę kierunków perspektywicznych (informatyka, hotelarstwo itd.).

${ }^{5}$ Por. Bank Danych SIO. 
TABELA. 2. Szacunek podaży pracowników $\mathrm{z}$ wykształceniem zasadniczym zawodowym w specjalnościach włókienniczo-odzieżowych w latach 2010-2025

\begin{tabular}{|c|c|c|c|c|c|c|}
\hline \multirow{2}{*}{ Lata } & \multicolumn{2}{|c|}{ Wariant pesymistyczny } & \multicolumn{2}{c|}{ Wariant podstawowy } & \multicolumn{2}{c|}{ Wariant optymistyczny } \\
\cline { 2 - 7 } & osoby & $\mathbf{2 0 1 0 = 1 0 0}$ & osoby & $\mathbf{2 0 1 0 = 1 0 0}$ & osoby & $\mathbf{2 0 1 0 = 1 0 0}$ \\
\hline 2010 & 23142 & 100,0 & 23142 & 100,0 & 23142 & 100,0 \\
2015 & 19041 & 82,3 & 19114 & 82,6 & 19203 & 83,0 \\
2020 & 16198 & 70,0 & 16389 & 70,8 & 16660 & 72,0 \\
2025 & 13900 & 60,1 & 14237 & 61,5 & 14796 & 63,9 \\
\hline
\end{tabular}

Źródło: obliczenia własne na podstawie danych GUS (BDL) i Ministerstwa Edukacji (SIO).

\subsection{Prognozy popytu na pracę absolwentów zasadniczych szkół zawodowych, kształcących w zawodach włókienniczo-odzieżowych}

Prognoza popytu na pracę (na techników odzieży i włókienników oraz absolwentów zasadniczych szkół zawodowych o profilu włókienniczo-odzieżowym) została dokonana za pomocą estymacji równania popytu na pracę dla sektora włókienniczo-odzieżowego na podstawie danych za lata 1999-2010 (tzn. od momentu zmiany podziału terytorialnego kraju i utworzenia województwa łódzkiego w obecnych granicach) ${ }^{6}$.

Na podstawie przeprowadzonych szacunków można zauważyć wyraźną tendencję spadkową zatrudnienia w latach 1999-2010. W przemyśle włókienniczym średnioroczny spadek zatrudnienia wynosił około 823 pracowników, a w przemyśle odzieżowym około 1684 pracowników. Stworzone modele ekonometryczne są dobrze dopasowane do rzeczywistego przebiegu procesów ograniczania zatrudnienia, gdyż w przemyśle włókienniczym model opisuje $92 \%$ całkowitej zmienności zatrudnienia, a w przemyśle odzieżowym $96 \%$. Oceny parametrów są statystycznie istotne.

Prognozy zatrudnienia w przemyśle włókienniczym i odzieżowym, przygotowane na lata 2015-2025, wskazuja podobny poziom wskaźnika zmian zatrudnienia w podstawowym wariancie prognozy, który zakłada spadek zatrudnienia w tempie 5,45\% rocznie (tabela 3.). Wyraźniejsze zróżnicowanie tempa zmian zatrudnienia pomiędzy przemysłem odzieżowym a włókienniczym jest zauważalne dopiero po analizie poszczególnych wariantów prognoz. Na przestrzeni badanych okresów pięcioletnich będzie się zmniejszało zapotrzebowanie na pracę - zarówno w przemyśle odzieżowym, jak i włókienniczym, przy założeniu braku zmiany dotychczasowej koniunktury rynku pracy w tych branżach.

${ }^{6}$ Pełny opis dokonanych estymacji znajduje się w raporcie: Pawełczyk A., Rogozińska-Pawełczyk A. pt.:„Przyszłość zawodów w sektorze włókienniczo-odzieżowym”, opracowanym w ramach projektu „Szyte na miarę kwalifikacje przyszłością sektora włókienniczo-odzieżowego w łódzkim”, Łódź 2012. 
TABELA. 3.

Prognozy zatrudnienia w przemyśle włókienniczym i odzieżowym na lata $2010-2025$

\begin{tabular}{|c|c|c|c|c|c|c|}
\hline \multirow{2}{*}{ Rok } & \multicolumn{3}{|c|}{ Przemysł włókienniczy } & \multicolumn{3}{c|}{ Przemysł odzieżowy } \\
\cline { 2 - 7 } & $\begin{array}{c}\text { Wariant } \\
\text { podsta- } \\
\text { wowy }\end{array}$ & $\begin{array}{c}\text { Wariant } \\
\text { optymi- } \\
\text { styczny }\end{array}$ & $\begin{array}{c}\text { Wariant pe- } \\
\text { symistycz- } \\
\text { ny }\end{array}$ & $\begin{array}{c}\text { Wariant } \\
\text { podsta- } \\
\text { wowy }\end{array}$ & $\begin{array}{c}\text { Wariant } \\
\text { optymis- } \\
\text { tyczny }\end{array}$ & $\begin{array}{c}\text { Wariant } \\
\text { pesymis- } \\
\text { tyczny }\end{array}$ \\
\hline 2010 & 11561 & 11561 & 11561 & 25033 & 25033 & 25033 \\
2015 & 9114 & 9401 & 8834 & 17614 & 17987 & 17248 \\
2020 & 6886 & 7382 & 6419 & 13313 & 13955 & 12697 \\
2025 & 5202 & 5797 & 4664 & 10062 & 10827 & 9348 \\
\hline
\end{tabular}

Źródło: opracowanie na podstawie własnych obliczeń.

W celu określenia popytu na techników odzieży i techników włókienników oraz na absolwentów szkół zawodowych, dokonano oszacowania udziału tych grup w zatrudnieniu ogółem. Było to możliwe jedynie na podstawie wyników ankiety przeprowadzonej wśród przedsiębiorców. Podobnie jak w przypadku analiz scenariuszowych, do oszacowania udziałów obu grup pracowniczych w zatrudnieniu ogółem zostały wykorzystane udziały obserwowane w próbie.

Przy założeniu utrzymania obserwowanych w badanym okresie obserwacji tendencji i przy niezmienionych w stosunku do obserwacji z próby losowej udziałach badanych grup pracowników w zatrudnieniu ogółem, w 2025 roku prognozuje się spadek liczby zatrudnionych techników odzieży i włókienników z poziomu 1829 osób na poziom 763 osób (tabela 4.).

TABELA 4.

Prognoza popytu na pracowników sektora włókienniczo odzieżowego według grup wykształcenia

\begin{tabular}{|l|r|r|r|r|r|r|r|r|r|}
\hline \multirow{3}{*}{ Rok } & \multicolumn{8}{|c|}{ Ogółem sektor włókienniczo-odzieżowy } \\
\cline { 2 - 10 } & \multicolumn{2}{|c|}{ Wariant podstawowy } & \multicolumn{2}{|c|}{ Wariant optymistyczny } & \multicolumn{3}{|c|}{ Wariant pesymistyczny } \\
\cline { 2 - 10 } & ogółem & $\begin{array}{c}\text { w tym } \\
\text { technicy }\end{array}$ & $\begin{array}{r}\text { w tym } \\
\text { po ZSZ }\end{array}$ & ogółem & $\begin{array}{r}\text { w tym } \\
\text { technicy }\end{array}$ & $\begin{array}{c}\text { w tym } \\
\text { po ZSZ }\end{array}$ & ogółem & $\begin{array}{c}\text { w tym } \\
\text { technicy }\end{array}$ & $\begin{array}{r}\text { w tym } \\
\text { po ZSZ }\end{array}$ \\
\hline 2010 & 36594 & 1829 & 21005 & 36594 & 1829 & 21005 & 36594 & 1829 & 21005 \\
2015 & 26728 & 1337 & 15342 & 27388 & 1370 & 15720 & 26082 & 1305 & 14971 \\
2020 & 20199 & 1010 & 11594 & 21337 & 1067 & 12247 & 19116 & 956 & 10973 \\
2025 & 15264 & 763 & 8762 & 16624 & 832 & 9543 & 14012 & 701 & 8043 \\
\hline
\end{tabular}

Źródło: opracowanie na podstawie własnych obliczeń.

Zebrany materiał empiryczny daje pewne powody do założenia, że liczba zatrudnionych pracowników sektora włókienniczo-odzieżowego, którzy ukończyli zasadnicze szkoły zawodowe, zmniejszy się z 21005 do 8762 osób. Przy analizie niniejszych wyników należy pamiętać o poczynionych wcześniej założeniach, bowiem nie jest pewne, czy zostaną one spełnione w przyszłości. Jednak zamierzeniem prognozy ostrzegawczej było pokazanie konsekwencji istnienia w przyszłości określonych warunków obowiązujących w okresie wyjściowym. 


\section{Bilans podaży i popytu na pracę $w$ sektorze włókienniczo-odzieżowym w perspektywie lat: 2015, 2020 i 2025}

Prognoza popytu i podaży na pracowników technicznych w latach 2015-2025 wskazuje istnienie pogłębiającej się luki popytowej, w przypadku gdy tendencje na rynku pracy sektora włókienniczo-odzieżowego, obserwowane w ubiegłej dekadzie, będą kontynuowane. Nadwyżka podaży techników odzieży i włókiennictwa, prognozowana na 202 osoby w 2010 roku, wzrośnie w wariantach podstawowych do 572 osób w 2015 roku, 845 osób w 2020 roku i 1068 osób w 2025 roku. Nadmiar absolwentów szkół zasadniczych będzie rósł z poziomu 2137 w 2010 roku do 3 772, 4795 i 5475 osób, odpowiednio w latach: 2015, 2020 i 2025. Szybkość i skalę, w jakiej narasta luka popytowa na prognozowanym rynku pracy, można zaobserwować w tabeli 5.

TABELA 5.

Bilans podaży i popytu dla pracowników technicznych w latach 2010-2025 w wariancie podstawowym

\begin{tabular}{|c|c|c|c|c|c|c|}
\hline \multirow{2}{*}{ Rok } & \multicolumn{3}{|c|}{ Technicy } & \multicolumn{3}{c|}{ Absolwenci ZSZ } \\
\cline { 2 - 7 } & Podaż & Popyt & Różnica & Podaż & Popyt & Różnica \\
\hline 2010 & 2031 & 1829 & +202 & 23142 & 21005 & +2137 \\
2015 & 1909 & 1337 & +572 & 19114 & 15342 & +3772 \\
2020 & 1855 & 1010 & +845 & 16389 & 11594 & +4795 \\
2025 & 1831 & 763 & +1068 & 14237 & 8762 & +5475 \\
\hline
\end{tabular}

Źródło: opracowanie na podstawie własnych obliczeń.

Bilans podaży i popytu dla pracowników technicznych w latach 2010-2025 wskazuje narastanie nadwyżek podaży, zarówno dla wersji optymistycznej popytu, który jest najbardziej korzystny dla absolwentów techników i szkół zasadniczych, jak i dla wersji pesymistycznej podaży. Co prawda dzieje się to, w wyraźnie mniejszej skali: dla techników wzrost wynosi do 854 osób, a dla absolwentów szkół zasadniczych do 4357 osób w 2025 roku (tabela 6.).

TABELA 6.

Bilans podaży i popytu dla pracowników technicznych w latach 2010 -2025 dla wersji optymistycznej popytu i wersji pesymistycznej podaży

\begin{tabular}{|c|c|c|c|c|c|c|}
\hline \multirow{2}{*}{ Rok } & \multicolumn{3}{|c|}{ Technicy } & \multicolumn{3}{c|}{ Absolwenci ZSZ } \\
\cline { 2 - 7 } & $\begin{array}{c}\text { Podaż wer- } \\
\text { sja pesymis- } \\
\text { tyczna }\end{array}$ & $\begin{array}{c}\text { Popyt wer- } \\
\text { sja optymis- } \\
\text { tyczna }\end{array}$ & Różnica & $\begin{array}{c}\text { Podaż wer- } \\
\text { sja pesymis- } \\
\text { tyczna }\end{array}$ & $\begin{array}{c}\text { Popyt wer- } \\
\text { sja optymis- } \\
\text { tyczna. }\end{array}$ & Różnica \\
\hline 2010 & 2031 & 1829 & +202 & 23142 & 21005 & +2137 \\
2015 & 1851 & 1370 & +481 & 19041 & 15720 & +3321 \\
2020 & 1751 & 1067 & +684 & 16198 & 12247 & +3951 \\
2025 & 1686 & 832 & +854 & 13900 & 9543 & +4357 \\
\hline
\end{tabular}

Źródło: opracowanie na podstawie własnych obliczeń. 


\section{Podsumowanie}

Podsumowując uzyskane wyniki i prognozy, należy wziąć pod uwagę to, czy rzeczywiście dany wariant zmian wystąpi. Niewatpliwie, nie jest to jeszcze przesądzone. Scenariusze i prognozy ostrzegawcze nie odpowiadają na pytanie: „Co się zdarzy w przyszłości”, ale maja za zadanie jedynie odpowiedź na pytanie: „Co by było, gdyby..., przy spełnieniu określonych założeń. Na rynku pracy działa sprzężenie zwrotne między popytem a podażą.

Narastanie nadwyżki podaży wykwalifikowanych pracowników sektora włókienniczo-odzieżowego powinno być więc już sygnałem dla gimnazjalistów o braku dobrych perspektyw zatrudnienia i realizacji kariery zawodowej po ukończeniu tego kierunku kształcenia. Scenariusz pesymistyczny przewiduje, że może zmniejszyć się jeszcze bardziej nabór do szkół kształcących w specjalnościach włókienniczo-odzieżowych, a w krańcowym przypadku doprowadzić do całkowitej likwidacji szkół tego typu (taka sytuacja miała miejsce w przypadku techników o specjalizacji włókienniczej). Taki wariant zapewne nie zrealizuje się do końca, choćby dlatego, że wówczas sytuacja uległaby odwróceniu. W miejsce nadwyżki podaży może pojawić się nadwyżka popytu. To zmusiłoby przedsiębiorców do reaktywacji systemu kształcenia we własnym zakresie w szkołach przyzakładowych. Całkowita zapaść systemu kształcenia zawodowego w segmencie włókienniczo-odzieżowym byłaby społecznie kosztowna i trudna do poprawienia w dalszej perspektywie.

Jak wspomniano w początkowej części artykułu, tylko organizacja ścisłej współpracy szkół z przedsiębiorstwami gwarantuje utrzymanie optymalnej strategii w zakresie polityki oświatowej. Szkolnictwo zawodowe w specjalnościach włókienniczo-odzieżowych musiałoby sprostać spadkowi popytu do czasu, gdy obniżająca się w wyniku procesów demograficznych liczba ludności w wieku produkcyjnym doprowadzi do redukcji podaży pracowników, zmieniając jakościowo sytuację na rynku pracy. Obopólna współpraca powinna także oznaczać szersza partycypację przedsiębiorców w szkoleniu praktycznym, zapewniając uczniom możliwość poznania nowoczesnych technologii produkcji, których w szkołach z natury rzeczy poznać nie są w stanie. Przedsiębiorcy winni zaangażować się także materialnie w finansowanie nagród i stypendiów dla uczniów oraz zakup pomocy naukowych. Takie działania podniosą atrakcyjność nauki i odsuną zagrożenie całkowitej zapaści tego kierunku edukacji.

Rozwój form i zakresu kooperacji szkół i przedsiębiorstw wymaga również aktywności po stronie szkół i instytucji wspierających - głównie władz samorządowych szczebla powiatowego i kuratorium oświaty. To od nich będzie zależeć rozwój zróżnicowanych form współpracy z pracodawcami, organizacja: wspólnych projektów, praktyk i stażów, konkursów nagradzanych stypendiami lub gwarancjami zatrudnienia itp.

Zmiany systemu szkolnictwa zawodowego podlegaja głównie decyzjom władz oświatowych i samorządowych, a tym samym mogą być one stymulowane administracyjnie. Natomiast decyzje o wielkości zatrudnienia są podejmowane przez firmy, przede wszystkim na podstawie rachunku ekonomicznego. To przedsiębiorstwa, kalkulując zyski, decydują się na offshoring, czyli przeniesienie produkcji do krajów o niskich kosztach pro- 
dukcji. Stąd wydaje się, że przeprowadzona powyżej prognoza popytu na pracowników posiada wszelkie cechy wiarygodności.

O ile branżę odzieżową czeka sprostanie zjawisku offshoringu, o tyle włókiennictwo zmierza wyraźnie w kierunku transformacji technologicznej. Na rynku pojawia się coraz więcej firm wykorzystujących nowoczesne technologie i zautomatyzowane linie produkcyjne do wytwarzania zaawansowanych technicznie, nowoczesnych materiałów włókienniczych [Mackiewicz, Łaszkiewicz, Socha, 2011, s. 9]. To może wywołać poważne skutki w stosunku do szkolnictwa zawodowego. W tak nowoczesnych zakładach jest mało miejsca na pracę tradycyjnego włókiennika, tymczasem pracuje tam niewielka liczba osób o bardzo wysokich kwalifikacjach (na przykład po studiach inżynierskich). Należy więc przypuszczać, że w przyszłości nastapi dalszy spadek popytu na techników i absolwentów zasadniczych szkół zawodowych, także w tym segmencie przemysłu.

\section{Literatura}

Bank Danych Lokalnych GUS, dokument elektroniczny, tryb dostępu: [http://www.stat.gov.pl/bdl, data wejścia: 11.08.2013].

Baz̧a Danych Systemu Informacii Oświatowej (SIO) Ministerstwa Edukacji, dokument elektroniczny, tryb dostępu: [http://www.cie.men.gov.pl, data wejścia: 26.09.2013].

Baz̧a Danych Handlu Zagranicznego GUS, dokument elektroniczny, tryb dostępu: [http://www.stat.gov.pl/gus, [data wejścia: 12.09.2013].

Fabińska M. 2012 Dobre praktyki w sektorze wtókienniczo-odzięzonym - raport benchmarkingony, raport opracowany w ramach projektu „Szyte na miare kwalifikacje przyszłością sektora włókienniczo-odzieżowego w łódzkim”, Łódź.

Kubiak K. 2012 Analiza oferty edukacyjnej szkót zawodonych w kontekście potrzęb sektora wtókienniczo-odzieżowego, raport cząstkowy opracowany w ramach projektu „Szyte na miarę kwalifikacje przyszłością sektora włókienniczo-odzieżowego w łódzkim”, Łódź.

Kubiak K. 2012 Analiza porównawcza potencjału szkolnictwa zawodowego o profilu wtókienniczo-odzieżonym na obszarach miejskich $i$ wiejskich, raport cząstkowy opracowany w ramach projektu „Szyte na miarę kwalifikacje przyszłością sektora włókienniczo-odzieżowego w łódzkim”, Łódź.

Mackiewicz M., Łaszkiewicz E., Socha B. 2011 Prognozy i ogólne trendy gospodarcze istotne dla rozwoju bransiy wtókiennictwa w województwie tódそkim, raport opracowany w ramach projektu „Diagnoza szyta na miarę włókiennika”, INS-E, Lódź.

Pawełczyk A., Rogozińska-Pawełczyk A. 2012 Prayszłosić zawodów w sektorze wtókienniczo-odzieżonym, raport opracowany w ramach projektu „Szyte na miarę kwalifikacje przyszłością sektora włókienniczo-odzieżowego w łódzkim”, Łódź.

Program Ramony rozwoju səkelhictwa zawodowego dla potrzeb innowacyjnego sektora wtókienniczoodrięzowego w województwie tódrkim, końcowy raport badawczy opracowany w ramach projektu pt.: „Szyte na miarę kwalifikacje przyszłością sektora włókienniczo-odzieżowego w województwie łódzkim”, Łódź, 2012.

Rogut A. 2007 Barwy wtókiennictwa. Potencjał przemystu wtókienniczo-odzieżowego w województwie tódžkim, SWSPiZ, Łódź. 